\title{
Doing politics in the recent Arab uprisings: towards a political discourse analysis of the Arab Spring slogans
}

\author{
Belqes Al-Sowaidi, Felix Banda and Arwa Mansour
}

\begin{abstract}
The present paper aims to analyse a number of those slogans collected from the sit-in quarters in Egypt, Libya and Yemen. Using political discourse analysis, it unravels various typical discourse structures and strategies that are used in slogans in the construction of a sub-genre of political discourse in the Arab world. Drawing data from several mediums, including banners, wall graffiti, audio-visual instruments, chanting, speeches and songs, this paper tries to show the extent to which the slogans serve as a medium by which political complaints and comments are dispensed and consumed. This paper draws on a rhetorical analysis to find out their persuasive effect on shaping the Arab intellect and on the change of the political atmosphere in the region. Lastly, this paper attempts to show to what extent the slogans meet the standards of political discourse and whether they can be considered as a sub-genre of political discourse or not.
\end{abstract}

\section{Introduction}

The revolutionary tsunami which has broken out in several countries of the Middle East in the last few years has brought about a massive number of slogans and has initiated a new sub-genre of political discourse in the Arab world. Such slogans have been introduced via many mediums, including banners, wall graffiti, audio-visual instruments, chanting, speeches and songs. The present paper aims to analyse a number of slogans collected from the sit-in quarters in Egypt, Libya and Yemen. Using critical discourse analysis (CDA), particularly van Dijk's (1997) political dis- course analysis (PDA), various typical discourse structures and strategies that are used in slogans in the construction of a sub-genre of political discourse in the Arab world are unravelled (See Appendix for some relevant background internet sources).

In fact, slogans are not something new. The etymology of the word shows that the term is derived from the Gaelic slaughghairm which means 'army cry' or 'war cry' (Sharp, 1984). The word was used by the Scottish clan with a view to inspiring the members of the clan to fight fiercely for its protection or the extension of its glory (Sharp, 1984: v). Similarly, slogans have also played a vital role in inspiring people to unite and achieve the interests of their countries and to restore their national pride.

In general, although the slogans under investigation are crafted in different countries, they do represent the socio-cultural concerns of the Arab Nation at large. This paper 
classifies the slogans under several categories and comes out with a discourse analysis of them. It shall assume that the slogans reflect the use of language in the Arab society. At the same time, it is noted that the slogans are not attributable to known authors. However, they serve as a medium through which a considerable number of socio-political issues that are likely to be unmentionable elsewhere are raised. The slogans provide the medium through which message composers can state their cases in the knowledge they are on the safe side and are shielded from political or social sanctions that are likely to be imposed by authorities and the community on members with opposing views. Such sanctions or political revenges are very widespread in different Middle Eastern countries.

The present paper aims to find out to what extent the slogans which have reverberated in the uprisings of the Middle East serve as a medium by means of which political complaints and comments may be transmitted. In turn, the paper aims to find out whether those slogans meet the standards of political discourse (van Dijk, 1997) and whether they can be considered as a sub-genre of political discourse or not.

\section{Literature review}

Several studies have dealt with political discourse in general. The use of rhetoric operations, for instance, has been the focus of a considerable number of studies (e.g. Billig, 1991, 1995; Bitzer, 1981; Campbell and Jamieson, 1990; Chilton, 1988; Dolan and Dumm, 1993; Hirschman, 1991; Kiewe, 1994; Tetlock, 1993; Windt and Ingold, 1987).

Slogans have also attracted the attention of many scholars. Denton (1980), Sharp (1984) and Urdang and Robbins (1984) among others have examined their use in political discourse. The use of slogans as a means of displaying dominant ideology has also been investigated in a number of studies such as Condit and Lucaites (1993), Denton (1980), Kaul (2010) Lu (1999) and Lu (2004).

Studies on the Arab Spring slogans, however, are a rarity in proportion to the great bulk of the slogans produced. It can be safely said that the slogans of the Egyptian uprising have been given a special attention by a considerable number of scholars. A collection of papers on the translation of the discourse used by protesters in Al-Tahrir Square of Egypt was published in 2012: Keraitim and Mehrez (2012) have discussed the semiotics of the Egyptian revolution; Taba and Combs (2012) have dealt with the transformation discourse of the revolution; the translation of the visual output of the Tahrir and the street art of the revolution have been examined by Gribbon and Hawns (2012) and Sanders IV (2012); and the poetics of the uprising have been examined by Sanders IV and Visona (2012).

Another collection of studies on the language of the Arab Spring was published by Orient-Institut Studies in 2013. The collection includes papers that deal with the various arts of the revolution. Gonzalez-Quijano (2013) has dealt with the use of rap as an art of the revolution, Dubois (2013) has discussed the street songs of the Syrian revolution and Abaza (2013) has conducted a study on the use of satire, laughter and mourning in Cairo's Graffiti. The volume also includes Srage's (2013) study, which deals with the 
phenomenon of the 'clause equivalent' of the slogan 'Irhal', meaning go/get out/leave. Srage (2013) has argued that this one-word statement formulates a highly significant, semantically condensed verbal clause and concluded that young people adopted the form and content of this concise imperative in order to affirm their awareness of the priorities of political change, i.e. the departure of the regime.

Neggaz (2013) has analysed the linguistic transformations of Syrian Arabic that have been taking place since the start of the revolution in March 2011. That study has concluded that the Arabic language and its Syrian dialectal forms have witnessed some transformations such as new word formations, semantic changes and the creation of new proverbs. Although the title of the Neggaz study implies that it is concerned with linguistic transformations in general, that study is more concerned with the semantic change Syrian Arabic has witnessed because of the revolution.

In a similar vein, Lahlali (2014) has analysed some textual, social, cultural and political aspects of the slogans used during the Egyptian revolution of 2011. That analysis has shown that the slogans reflect a variety of themes and a diversity of political perspectives. It has concluded that the political orientation of Egyptian society has shaped the slogans. Furthermore, Lahlali (2014: 12) has pointed out that the language register used 'echoes the diversity of Egyptian society and the different political orientations of its groups, including, amongst others, Islamic, secularist and liberal views'.

In addition, Al-Haq and Hussein (2012) have attempted a sociolinguistic analysis of four hundred slogans collected from different places in Tunisia and Egypt using the internet, TV channels, and newspapers with a view to investigating the language functions that the slogans convey. Their analysis has revealed that slogans fulfil twenty linguistic functions among which humiliation constituted the prevailing one.

Colla (2012) has also conducted a study on the Arab Spring slogan 'the people want', pointing out that the slogan has been used excessively to the extent that it loses its glamour. Colla (2012) has argued that ambiguity has shadowed this slogan almost from the beginning and the slogan has been used as the discursive scaffolding for hanging every new demand, even though those demands are sometimes incoherent and contradictory.

It seems that most of the above studies are more concerned with the various art forms of the revolution rather than slogans in particular. Even those studies that deal with the Arab Spring slogans are more concerned with the topical and ideological aspects of the slogans rather than their linguistic features. In other words, they deal with the predominant topics involved in the slogans such as hope and aspiration, the call for reprimand and prosecution, the call for immediate resignation of presidents as well as the call for freedom and liberty. As a result, the above studies seem more related to political science rather than to PDA.

The current study is different from the studies available in the literature in a number of aspects. Firstly, the scope of study goes beyond the discourse of Egyptian revolution to the 
discourse used in other Arab countries. Despite the fact that all Arab Spring countries have gone through similar sufferings and troubles, some slogans have exhibited clear ideological and varietal differences. Secondly, unlike the above-mentioned studies, the current study does not only investigate the thematic aspects of the slogans; it rather attempts a detailed PDA of them with a view to finding out the strategies adopted by protesters to persuade the audience of the validity of their claims and to achieve what Chomsky and Herman (1988) called 'manufacturing consent'. As far as the current authors are aware, there are no studies that attempt a CDA or a PDA of the slogans. The current study is a PDA of the slogans because it is interested in 'tying language to politically, socially, or culturally contentious issues and in intervening in these issues in some way' (Gee and Handford, 2012: 5).

\section{Theoretical considerations}

Critical discourse analysis is used theoretically and analytically to unravel the ideologies and attitudes and power relations behind discourses whether written, oral or both. According to Fairclough (1995: 133), CDA is:

discourse analysis which aims to systematically explore often opaque relationships of causality and determination between (a) discursive practices, events and texts, and (b) wider social and cultural structures, relations and processes; to investigate how such practices, events and texts arise out of and are ideologically shaped by relations of power and struggles over power; and to explore how the opacity of these relationships between discourse and society is itself a factor in securing power and hegemony.

Although many studies have been done using CDA, especially in unravelling hegemonic discourses, ideologies, and the role and power structure embedded in both oral and written texts, there is a dearth of studies using PDA. However, the analytical framework for this paper is influenced by PDA as suggested by van Dijk (1997).

van Dijk has extensively published on CDA and he has particularly focused on 'the role of discourse in the (re)production and challenge of dominance' (van Dijk, 1993: 283). van Dijk (1997) has introduced PDA as an extension of CDA admitting that it is a broad and an ambiguous concept that may refer to the analysis of 'political discourse' or to a political approach to discourse and discourse analysis, as is the case with CDA. PDA, within the framework of CDA is mainly concerned with the the reproduction of political power, power abuse or domination through political discourse, including the various forms of resistance or counter-power against such forms of discursive dominance' (van Dijk, 1997: 11).

According to van Dijk (1997), political discourse is determined by its actors such as politicians (e.g. the presidents, the prime ministers, political institutions, etc.). This refers to the kind of discourse generated by politicians in fulfilling their political mandates, as in addressing political meetings. 
Despite his argument that PDA can be narrowed down to the set of activities politicians engage in, van Dijk (1997) has pointed out that politicians are not the only participants in the domain of politics and thus PDA should also include the various recipients in political communicative events, such as the public, the people, citizens, the masses, and other groups or categories' (van Dijk, 1997: 13).

That is to say, political discourse may go beyond the circles of professional politicians and political institutions to involve different recipients of the communicative event such as the public.

Defining political discourse is, therefore, not a straightforward matter. While some analysts restrict it to politicians and core political events, other analysts define it so broadly that almost any discourse may be considered political. van Dijk (1997: 15) has warned against the extension of the scope of political discourse saying:

However, in order to avoid the extension of politics and political discourse to a domain that is so large that it would coincide with the study of public discourse in general we shall not treat such forms of discourse-with-possible-political-effects as political discourse. That is, corporate, medical or educational discourse, even when public and even when affecting the life of (many) citizens, will here not be included as forms of political discourse. And although we may readily subscribe to the well-known feminist slogan that the personal is political, we shall similarly not take all interpersonal talk (not even of gender) as political discourse.

Based on the participants and the content of the slogans, it can be argued that the Arab Spring slogans constitute a political discourse. The context of the political discourse of the study under investigation involves a myriad of participants. That is to say, political parties, the mass people, work unions, educators, students, proletarians, women associations, ethnic groups, etc. are involved in various political activities including peaceful demonstrating, protesting, civil disobedience and long marches. In terms of content, the slogans deal with a range of politically-related issues such as political change, dictatorship, oppression, democracy, justice, freedom, equality, accountability, reconciliation, toppling the regimes and trialling their officials, etc. However, participants and content may not be sufficiently decisive factors to label slogans as a political discourse. A consideration of the text and its context is a basic criterion to determine whether a text or discourse is a proper political discourse or not.

Hence, to locate the Arab Spring slogans in the realm of political discourse, the focus should not only be on the participants or the topics, but rather there is a need to investigate other discourse structures. Although van Dijk (1997: 25) has argued that the structures of political discourse are seldom exclusive, he has emphasized that 'typical and effective discourse in political contexts may well have preferred structures and strategies that are functional in the adequate accomplishment of political actions in political contexts' (van Dijk, 1997: 25). Those various levels and dimensions of discourse structure 
need to be examined if seeking the typical discourse structures and strategies that have 'this status of preferred discursive methods of doing politics' (van Dijk, 1997: 25).

Since the early 1980s, political discourse has been tackled from different perspectives (e.g. descriptive, psychological and critical). However, following a descriptive approach or a psychological approach is not sufficient to have a detailed PDA of any political event. The approach of discourse structures advocated by van Dijk has been chosen because it strikes a balance between linguistic analysis and political analysis. PDA can have a lot to offer political science and can contribute to answering genuine political questions if it focuses on features of discourse that are relevant to the purpose or function of the political process or event whose discursive dimension is being analysed (van Dijk, 1997: 38). It is argued here that focusing on the discourse structures of slogans is relevant in precisely this sense, as the purpose of the slogans may be to convince the audience (i.e. citizens, the Arab nation and the international community) that a certain course of action or view is right. The predominant role of language and discourse structures in PDA is also echoed by Wilson (2003: 13) who has argued that 'certain core features will, and must, remain constant in the field of political discourse, and central to this is the role of language and language structure, and its manipulation for political message construction and political effect'.

In terms of discourse structures, van Dijk (1997) has argued that political discourse is often organized around particular topics, superstructures or textual 'schemata', local semantics, lexicon, syntax, rhetorical operations, expression structures and speech acts. The current paper seeks to determine to what extent some of these discourse structures are deployed in the Arab Spring slogans.

\section{Methodological issues Data collection}

The data of the study consists of the transcripts of a number of slogans that were used by the demonstrators in some Arab countries, namely, Egypt, Libya and Yemen. The slogans appeared on the banners raised by demonstrators or were repeatedly verbally chanted during demonstrations. The slogans were widely circulated by various TV channels (e.g. Aljazeera, Al-Arabiya and BBC Arabic) and in various media articles, blogs, videos and social networks including Facebook and Twitter. The collected slogans deal with various socio-political issues in the three Arab countries mentioned above but have implications for the entire Arab world in general. They straddle colloquial and standard Arabic and serve as a microcosm for the slogans used in other Arab Spring countries. The current study totally agrees with Colla (2012) who has argued that the Egyptians like the Tunisians before them were aware that 'they were not only singing to themselves - they were self-consciously performing revolution for the entire Arab world'. Thus the selection of the slogans is not motivated by political considerations (e.g. failing states vs. non-failing ones), simply because all the Arab states that witnessed uprisings are failing in the eyes of the protesters. It can be claimed that the Arab Spring slogans are homogeneous and they share a lot in common even though their discursive content is sometimes slightly localized (i.e. looks more Egyptian, Yemeni or Libyan ). 
All the slogans were kept intact and they did not undergo any modifications or corrections. In this paper, 62 tokens of the slogans collected are used as the database for analysis.

\section{Data analysis}

The co-evolution of language and politics is undeniable. Chilton (2004: 16) has aptly pointed out that 'political actors themselves are well aware of the importance of how language is used even in the act of denying the fact'. The protesters have therefore employed a lengthy list of politico-linguistic devices to resist the power of the regimes in their relevant countries. The current analysis attempts to find out the various discourse structures used by protesters with a view to representing their ideological square 'de/emphasize good/bad things of US/Them' (van Dijk, 1998).

The slogans will be analysed within the framework of CDA. In particular, van Dijk's (1997) PDA will be used. As suggested by van Dijk (1997) the various typical discourse structures and strategies that pertain to political discourse at various levels and dimensions will be discussed. The focus is on the slogan's topics, textual schemata, local semantics, lexicon, syntax, rhetoric, expression structures and speech acts. In doing so, the current study will be in a position to show how Arab protesters who have been powerless for quite some time used the 'loaded weapon' (Bolinger, 1980) called language to mock, oppose and resist the discourse of the totalitarian regimes that have used language to control, marginalize, assimilate and eliminate them for decades. It has to be made clear that although this study's analysis is politico-linguistic, it is more concerned with the manipulation of language in the slogans since, in general, this is what differentiates PDA from other areas of political research found, say, in political science.

\section{Discussion}

\section{Topics}

van Dijk argues that 'topica' or 'typology' is not given enough attention in discourse analysis. Topica refers to the analysis of diverse discourses, what they mean, the situations surrounding them and the contexts in which they occur (van Dijk, 1997: 26). Based on their contents, the Arab Spring slogans can be analysed under a number of topics relevant to protesters' religious, socio-economic, cultural and political perspectives.

Political humour and satire. van Dijk (1997: 28) suggests that political topics are mainly about political actors. Arab ex-leaders and their actions were a matter of ridicule in a number of slogans. A considerable number of humorous and satirical slogans were on the lips of Arab protesters. The current study finds that protestors use their knowledge of Arab culture and rhetoric to generate satirical messages embedded in political humour. In Libya, for instance, some of the slogans read as in (1):

1. Al-sha'b yūrìd 'iläj al-za'ìm. [The people want the treatment of the leader.]Alsha'b yurìd tafsìr al-khitāab. [The people want to interpret the speech of Qathafi.] Al- 
sha'b yurìd hubūb halwasah mārikat Al-Qadhāfi. [The People want Qathafi Brand hallucination tablets.]

In each case, the famous Arab-world-wide slogan al-sha'b yurīd isqāt al-nizāam 'The people want the fall of the regime' has been twisted and modified satirically. In the first slogan, the addresser wants to say that the Libyan people want to treat their leader as insane. This slogan is released as a response to the first speech delivered by Qadhafi in the aftermath of the outbreak of the Libyan uprising in Bani Ghazi and Al-Baida'a. In that speech, he appeared stressed and bizarre. He incoherently talked about different issues and thus the slogan refers to this aspect of the speech. In the same speech, Qadhafi accused the opposition of providing the youth with drugs and thus they were fighting him because they were in a state of intoxication. Therefore, the revolutionaries satirically responded to him saying that they have given up hashish and are really looking for Qadhafi-brand drugs.

Expression of political humour and satire is not only through linguistic means alone, but also through multimodality, which combines verbal and visual semiotic materials to generate political messages. Consider the multimodal political humour in (2):

\section{Al-sha'b yurīd taghyīr al-ța'àm. [The people want the change of the food.]}

In Egypt, the above slogan appears under a picture of a bowl of butter beans to refer to the famous national dish in the Sudan and Egypt. Thus, the message is that protesters, here, no longer wish the fall or the change of the regime but rather the change of the food they have been eating day and night. The multimodal discourse structures suggest that mere change in regime is nothing if the well-being of the people remains a matter of great concern.

In the slogans above, $a l$-sha' $b$ 'the people' is the participant; the action of changing the regime, the opinion of having Qadhafi drug, or changing the food all have 'a general, official, institutional or public nature' (van Dijk, 1997: 26). The slogans show a general decision taken by the people to control the political process and to oppose and challenge its policies, as well as to point at a different and better future for the ordinary citizens.

Political evaluation. van Dijk (1997: 28) posits that topics often feature typical polarized appraisals of 'politicians, public figures, and organizations and their actions'. The corpus shows several instances of references to politicians and their actions. Some of the evaluations are in the form of swear words directed at presidents, their wives or at their political systems as a whole. Consider, for example, slogan (3):

3. Șāhib al-ḍarbah al-jawiyah hua kabīr al-balțajiyah. [The person who led the air strike [on Israel and of whom we were proud] is the greatest of thugs.]

In (3), Mubarak of Egypt has been described to be baltaji 'a thug'. This word has been widely circulated throughout the Arab World. It is a swear and colloquial word that means 
the person who takes advantage of power and abuses or mistreats others verbally, emotionally or physically. Thus, takes advantage of power and abuses or mistreats others verbally, emotionally or physically. Thus,

Mubarak, the pilot, who is believed to be the leader of the successful 1973 air strike on Israel, is described as the greatest of all thugs. Another example of political insult is given in (4):

4. Ya Mu'amar ya abu shafshufah al-sha'b al-lībi tauwah tashufah. [O Muamar, whose hair can never be combed, you will see now how easily the Libyan people can topple you.]

Here, abu shafshufah is a relatively new term in Arabic. It has not been in use before the Libyan uprising. It refers to the uncombed hair of Qadhafi, which is part of his strange personality as they claim.

The slogans above depict what van Dijk describes as the 'strategic principle of all ideological and political discourse...Emphasis/de-emphasis of Our/Their Good/Bad Actions' (van Dijk, 1997: 28). Thus, Qadhafi's apparently unkempt hair is exaggerated to emphasize his strange characteristics.

Political threats. Political discourse is also replete with political threats aimed at real or perceived political opponents. Threats of revolt or insurrection against the regime are used in the predicates of several slogans and in all the countries that witnessed the uprisings. Consider, for example, the following slogans:

5. Lāazim lāzim Ḥusni yaghūr ... qā idīn huna 9 shuhūr. [Husni must step down. [For this cause], we are ready to stay [in squares] for nine months.]

6. Mush hanihda mush haninām hata yasqut al-niẓām. [We will neither slow down [the pace of our protest] nor will we have a wink of sleep till the fall of the regime.]

In these slogans, threats are directed to the Egyptian former president personally and to his regime. In (5), Mubarak must disappear and leave power; otherwise, the protesters will patiently remain in the freedom squares for months. In (6), however, the whole regime is threatened by the protesters who are determined to escalate their activities until the fall of the regime.

\section{Nationalism, resentment of current policies and accountability.}

Slogans have also dealt with various aspects of the political domain. The demands of the protesters are not confined to their domestic affairs. National issues in general and the Palestinian Cause in particular have found their own place in the slogans. Egyptians, who are viewed as the pioneers of Arab Nationalism, are not pleased with their country's stance towards the Palestinians, as is clear in (7): 
7. Husni biyh Ḥusni biyh quli muhạașir Ghazah liyh. [Hosni, Bey! Hosni, Bey, tell me, 'why do you siege Gaza?']

Here, the demonstrators are trying to find out a justified and convincing answer from Mubarak for the blockade they claim he put on Gaza. The slogan exhibits their resentment at what they deem a savage policy that aggravates the sufferings of their Palestinian brothers. Even worse, their regime prevents the flow of essential needs for the Palestinians while it supplies Israel with gas at trivial prices. This issue of selling gas to Israel provokes the Egyptians even more and they chanted:

8. $\quad B \bar{a} ' \bar{u}$ al-dawlah wa bā' $\bar{u}$ al-ghāz ... dūl 'awizin al-wal'ah bi-jāz. [They sold out the state, the sold out the gas. We need to ignite gas and burn them to death.]

That is, the regime needs to be burnt because it wastes the natural resources of the country by selling the gas for low prices that are not in harmony with the global prices.

\section{Standard of living.}

Political discourse does not refer only to various elements of the political domain; it usually combines its topics with those from other societal domains (van Dijk, 1997: 25). A considerable number of people in the Arab Spring countries live under or just above the poverty line, which the World Bank sets at $\$ 2$ a day (The World Bank, 2013). The standard of living and the miserable conditions of most of the Arabs are, therefore, reflected in the slogans, as is clear in (9):

9. Ya Suzān quī li-al-biyh kilo al-'ds bi-'asharah jiniyh. [O Suzan! tell the Bey, one $\mathrm{kg}$ of lentils costs ten Egyptian pounds.]

Here, people who are afflicted with poverty cannot even get their essential needs. Lentils, which is the national dish for a high percentage of Egyptians is no longer affordable. A kilo of lentils costs ten Egyptian pounds. Another example is given in (10):

10. Hū yalbas ākhar mawḍah wa-ḥna ni-nām al-'ashrah bi-'uḍah. [While [the president] wears the latest fashion trends, ten of us sleep in a stuffy room.]

Here, the housing crisis that bothers most of the Egyptians is highlighted in the slogans. In (10), while the president is very wealthy and leads a very comfortable life wearing the latest fashion, the poor citizens cannot find a proper accommodation. Ten people share a single room.

\section{Superstructures or textual 'schemata'}

Each discourse genre is characterized by schematic forms that differ according to the communicative goal, audience, information load, etc. (Grabe and Kaplan, 1996: 54ff; Swales, 1990; van Dijk, 1997: 29). Political slogans like any other genre have their own schematic patterning. That is to say, they have particular canonical and conventional forms that define their genre membership. Protesters promote their ideas by using brief, 
clear, eye-catching and musical slogans that easily stick to minds due to their special sound pattern. Parallelism, antimetabole, colloquialism, alliteration, assonance and antithesis are all devices of the textual schemata of political slogans. A detailed analysis of these devices is given in the Rhetorical Operations section.

Another schematic feature resides in the tendency of the composers of slogans to violate syntactic, stylistic and rhetorical norms to communicate particular political messages. In fact, this is not a disadvantage of slogans; it is rather a merit. As Crystal points out 'there are several situations where it is perfectly in order to be strange, and indeed where the breaking of linguistic rules is seen as a positive feature of communication' (Crystal, 2003: 400). Thus, by violating certain linguistic and rhetorical norms slogans are able to communicate their message efficaciously. Besides, slogans can be multimodal in the sense that they convey their communicative goal through both image and text. Some slogans are painted onto banners along with pictures of martyrs or/and opponents. Multimodal slogans tend to promote the image of the revolutionaries and to distort the image of opponents. A Yemeni slogan, for example, contains a photograph of one of the martyrs and a distorted photograph of the Yemeni former president in which he appears burnt beyond recognition along with his notorious nickname 'afäsh. The slogan reads alsha'ab yurìd muhakamat al-safāh 'the people want the trail of the shedder of blood'. Other slogans are even supplemented with some cartoons as in the following:

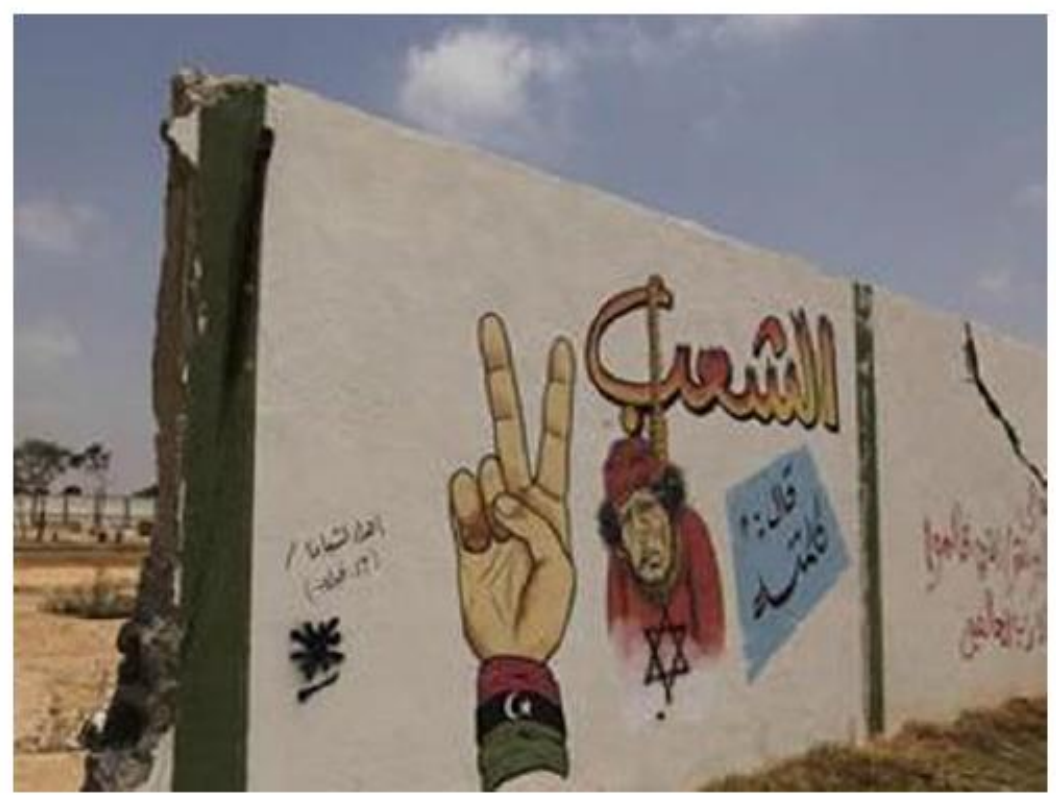

Source: Sublat 'umān (2011)

Here, the slogan 'the people want to topple the regime' is represented in the form of a cartoon. A hand is shown and two fingers are up, a well-known symbol of victory or martyrdom. The slogan al-sha'ab qāla kalimatah 'the people has said his say' is emphasized in the cartoon by a bold and large font and a rope was hanging around the neck of Qathafi. The cartoon has made meanings more 'prominent for obvious partisan reasons' (van Dijk, 1997: 29). 
It can be argued that the slogans genre has some schematic features that do not even concur with logical reasoning. However, slogans become catchier when they deviate from the norms. Besides, slogans can be flexible in their schematic forms. Although brevity is a canonical feature of slogans, the Arab Spring brings with it some intertexual slogans that cite the opening lines of famous Arab poets such as Abu Al-Qasim Al-Shābi's 1933 poem, 'The will to live'.

In brief, the schematic forms of slogans tend to emphasize some meaning for obvious partisan reasons (i.e. to promote their beliefs, ideas, etc.) and thus they foreground them. They, however, hide significant information if it is negative to their cause by putting it in less prominent textual categories or by deleting it altogether (van Dijk, 1997: 29).

\section{Local semantics and lexicon}

Those involved in political discourse, according to van Dijk (1997: 30) 'tend to emphasize all meanings that are positive about themselves and their own group (nation, party, ideology, etc.) and negative about the Others, while they will hide, mitigate, play-down, leave implicit, etc. information that will give them a bad impression and their opponents a good impression'. A cursory look the slogans shows that the slogans related to the revolutionaries carry positive meanings. They present the anti-regime activists as the Utopian and unified group that aspires to change the society for the best. In reality, however, political parties that participated in the uprising embrace different ideologies and policies and they never act as a unified group. For instance, while the socialists, Islamists, communists, Nasserites and many others played a vital role in the uprisings and there is a long history of conflict and poor governance among those groups, the slogans do not contain information that may bring bad fame to those forces. Despite the fact that some of those factions, as noted above have been in power before and they did not rule their countries properly too, there is not even a single slogan that refers to their past.

At the lexical level, the choice of the words shows a very clear kind of bias for 'partisan principles of the Ideological Square' (van Dijk, 1997: 33). While the youth in all the Arab countries are thuwār 'revolutionaries', the pro-regimes are balātigah 'thugs'. While the youth are musālimīn 'peaceful', the others are 'irhābiyīn 'terrorists', qatalah 'murderers' and safāhin 'manslayers'. In addition, the youth are described in the slogans as alshabāb al-hilu 'the good people' and their opponents as al-shabāb al-wahish 'the bad people'. On the contrary, the regimes' alliances have described the 'peaceful revolution' of the youth as fawḍah 'chaos', takhrīb 'vandalism' and fitnah 'sabotage'. Sahạàt al-taghyīr 'Change squares' (where demonstrators rally), are described by opponents as sahāt altaghrīr 'delusion or misguidance squares'. Even the people who have been killed are sometimes called shuhadā 'martyrs' and at other times, they do not deserve that rank and they are just qatla 'killed people'.

Moreover, violent actions by both sides have been euphemized. In Yemen, for instance, some of the protesters have attacked the official institutions and have called them suqut 
silmi li-al-mu'asāsāt al-rasmiyah 'a peaceful fall of official institutions'. Thus, the attack on public institutions is a peaceful occupation (see: http://www.altagheer.com/news28542.html); the use of 'peaceful' in the previous collocation is a euphemized expression for a hostile act. Similarly, in all the Arab Spring countries, a considerable number of innocent people, protesters and security forces have been killed, but such killing of innocents is sometimes called difä'an 'an anafs 'self-defence' or qatl ghayr 'amd 'collateral killing'.

Hence, the anti-regimes and pro-regimes demonstrators have used a massive repertoire of words/expressions that should be collected and compiled. They have managed to 'create new sets of words to talk about things for which they previously used the same words as everybody else' (Fawcett, 1997: 5).

\section{Syntax and pro-forms}

van Dijk (1997) lists a number of morpho-syntactic features that are related to political discourse in English. These include the use of pronouns, variations of word order, the use of specific syntactic categories, active and passive constructions, nominalizations, clause embedding, sentence complexity and other ways to express underlying meanings in sentence structures. The current study's data show that the syntactic style is subtly manipulated in the slogans to project particular ideologies and stances.

\section{Use of pronouns.}

One of the syntactic features in political slogans is the use of deictic pronouns nahnu vs. hum (van Dijk, 1997). Such use of pronouns serves pragmatic and semantic functions (van Dijk, 1997). Consider, for instance, the slogan given in (10) above, in which, $h \bar{u}$ 'he' is used to refer to Mubarak and wihna 'we' refers to the Egyptian youth or the Egyptians in general. The slogan differentiates between the luxurious life of the president and the collective misery of the other Egyptians.

In other cases, the plural pronoun hum 'they' is used to refer to the whole regime, as is obvious in (11):

11. Huma bi yaklū hamām wa baț... wa kul al-sha'ab jaluh al-ḍaghț. [While they [the regime] eat pigeons and ducks, all the people get hypertension.]

In some other cases, the cataphoric pronoun nahnnu is used and followed directly with its reference as in (12):

12. Ya yaman naḥnu shabābik fatịīn li-thawrah bābik lā hizbyah wa lā aḥzāb thawratana thawrat shabāb [O Yemen! We are your youth We are opening your door to the uprising No partisanship! No parties, Our uprising is the uprising of the Youth.]

All the examples above clearly state the sense of solidarity and inclusion when it comes to the youth or the people and the sense of exclusion of the regime and its supporters. 


\section{Use of vocatives.}

Name-calling is widely used by politicians on different occasions. This strategy has been widely used in the slogans. The corpus shows a number of instances where the revolutionaries or the pro-regime supporters use vocatives followed by a name with a view to gaining advantage over, or defending themselves from opponents. The examples given below state this strategy:

13. Ya Qadhāfi ya jabān, al-sha' ab Al-lībì lā yuhān. [O Qathafi! O Coward! The Libyan people will not be disgraced.]

14. Ya 'ali ya safāh, baqi dahfah wa nirtāh. [O Ali! O shedder of blood! There is little time left and we will get rid of you.]

15. Ya Jamāl qūl la-būk ... al-sha' ab al-mișri yikrahūk. [O Jamal, Tell your father, 'the Egyptian people hate you'.]

In the above examples, the technique of name-calling is used by protesters to intentionally deride the Libyan, Yemeni and Egyptian former presidents and to construct negative impressions or opinions about them. Qadhafi is described as a coward, Saleh is viewed as a man indulging in bloodshed and Mubarak is hated and detested by his people. On other occasions, name-calling has been used in a sympathetic manner where people sympathize with political icons who actively participated in the development of their countries. An example of such icons is the late Yemeni president, whom the protesters address in (16):

16. Ya Ḥamdi 'ud 'ud ... sha'bak yishhat 'a-al-ḥudūd. [Oh Hamdi [the former president of Yemen], Come back! Come back! Your people are begging on the borders.]

In (16), the former president of Yemen, the Late Ibrahim Al-Hamdi is called. The slogan emotionally addresses him and tells him about the miserable conditions of his people. The people who used to have a thriving life during his reign have been turned into beggars.

Imperative sentences. Halliday (1994: 69) points out that there are four basic speech roles: giving information; demanding information; giving goods and services; and demanding goods and services. The last one refers to what is traditionally called Command. Demanding goods and services has been the mainstay of many slogans, as is clear in both (17) and (18):

17. Irḥal irḥal ya jabān ... ya 'amīl Al-Amrikān. [Depart! Depart! Coward. You are the agent of the Americans.]

18. Khudh 'ilatak wa itla' bara Libya ha-tibqa hurah. [Take your family and get out, Libya will remain free.]

In the two examples above, the command verbs Irhal and Khudh have been used to address the former Egyptian and Libyan presidents respectively to step down and to leave their countries. The use of such verbs reflects the defiant spirit of the protesters as well as 
their self-confidence of victory. In other words, it reflects their power as revolutionaries against the regime.

Halliday (1970) states that one function of imperative clauses is to command others to do something, as in (17) and (18); the other function is to invite the audience to do something together. The latter is usually indicated by the format 'Let's'. An example of this function is the slogan given below:

19. Nuḍ̄ nuḍ̄ ya Bani Ghāzī jalakī al-yawm alì titraji. [ Let’s Revolt, Let’s Revolt, Bani Ghazi!

What you wish has come true today.]

Antimetabole. Antimetabole is defined as 'Figure of emphasis in which the words in one phrase or clause are replicated, exactly or closely, in reverse grammatical order in the next phrase or clause; an inverted order of repeated words in adjacent phrases or clauses (AB, B-A)' (see: http://www. americanrhetoric.com/figures/antimetabole.htm). An example of antimetabole is given in (20):

20. Ra'ìs min ajl al-yaman là yaman min ajl al-ra' ìs. [A president for the sake of Yemen rather than Yemen for the sake of the president.]

\section{Ellipsis.}

Ellipsis is a cohesive device in which part of a structure is omitted. The use of ellipsis is common in the slogans as is obvious in (21) and (22) respectively:

21. Ya Qadhāfi dawrak ja ḍum al-khaymah wa dìr 'azā. [O Qathafi, your turn has come!

Remove your tent and start a mourning ceremony.]

22. Thawrah thawrah hata al-nașr ... bukra Libya tuhașil Mașr. [Our uprising will continue until we gain victory. Tomorrow Libya will follow Egypt.]

Slogan (21) can be interpreted as 'Oh, Qathafi, your turn to step down has come', but the part after dawrak 'turn' has been elipticized. Similarly, in (22), bukra Libya tuhașil mașr 'tomorrow, Libya will follow Egypt' contains an elliptical part that can be interpreted as 'tomorrow Libya will follow the track of revolution like Egypt.'

\section{Nominalization.}

Some of the slogans are nominalized in the sense that the verb has been turned into a noun. Such verbs are followed by an expanded noun phrase. This kind of structure is called iḍa fa or annexion phrase. Consider, for instance, (23) and (24):

23. Isqāt al-niẓām al-fardì al-'usarì al-istibdādì huwa mațlabuna. [Toppling the authoritarian individual family regime is our demand.]

24. Mațlabuna huwa tanhyat al-ra' ìs 'ali 'bda-allah Șalih 'an al-ri'asah wa käfat aqāribah min al-marākiz al-qiyādiyah fì al-mu'sāsāt al-'askiryah wa al-madaniyah. 
[Our demand is removing President Ali Abdullah Saleh from presidency and [removing] all his relatives from leadership positions in the military and civil institutions.]

Another common nominalization structure found in the slogans is that of a verbless nominal clause where a verb is elipticized, as (25) shows:

25. Libiya fī alqalb makānik. [Libya! in our hearts you are.]

In the above example, the verb that can be semantically interpreted as is or exists is omitted.

\section{Shifting word order.}

Some slogans deviate from the standard word order of Arabic for topicalization purposes. In other words, the verbal clause can be nominalized by changing the verb- subjectobject order to the subject-object-verb order. This shift in word order puts emphasis on the topic of the slogan.

In addition, the verb is used in the imperfect aspect in order to show the immediacy of the action even though the event has already occurred (Watson, 1999: 170). An example of this type of structure is the famous and widely-circulated slogan given in (26):

26. Al-sha ${ }^{\prime} b$ yurìd taghyìr al-niẓām. [The people want to change the regime.]

In the above example, the normal word order is yurìd al-sha' b taghyìr al-nizām, 'want the people the change of the regime'.

Although the people have already made up their mind and taken the initiative to topple the regimes, the imperfect aspect has been used.

In fact, $a l$-sha $b$ has been topicalized by all parties with a view to foregrounding their demands. While $a l$-sha' $b$ has been thematized in the slogans of the revolutionaries to emphasize the demand of toppling the regime, the same word has been thematized by the pro-regime allies to emphasize several demands, as is clear in the following slogans:

27. Al-sha'b yurìd ikhlā al-maydān. [The people want to evacuate the square [of protesters]].

28. Al-sha' b yurìd inhā al-'i tișām. [The people want to end sit-ins/protests.]

29. Al-sha $b$ yurìd hifz al-dima . [The people want to preserve lives.]

Topicalization has also been used by revolutionaries with an aim to emphasize the bad things of outgroups, as is obvious in (30):

3o. Al-imām Yaḥya 16 sanah... Al-imām Aḥmid 13 sanah... Al-imām 'ali 33 sanah. [Imam Yahia [has ruled for] 16 years... Imam Ahmed [for] 13 years... Imam Ali [for] 33 years.] 
In (30), the former president of Yemen has been foregrounded and described as an imam because he has ruled for more years than the notorious kings of Yemen, namely Imam Yahya and Imam Ahmed. This kind of syntactic topicalization emphasizes the president's lust for power and his tyranny. In line with van Dijk's (1997: 34) ideological square, syntactic topicalization emphasizes the good aspects of the anti-regime supporters and the bad ones of the regime and its supporters.

\section{Rhetorical operations}

The main goal of politics is to persuade. Rhetoric, therefore, plays a very vital role in this process of persuasion. The Arab Spring slogans are characterized by the employment of a 'smash hits' selection of rhetorical devices. The use of rhetorical devices makes slogans memorable and easy to be chanted and remembered. It is through those devices that the slogans reach a broad potential audience. Various Arab Spring slogans were also heavy in the extensive use of figures of speech. A few of these are illustrated below.

\section{Alliterations, rhyme and morphological repetition.}

Many slogans have employed deliberate use of phonic patterns for expressive purposes. Alliteration, for instance, is widely used. Alliteration is the repetition of the same sound in two or more words. This kind of sound repetition creates a musical tone that embellishes the language and helps the listeners or addressees enjoy it. Some slogans that use alliteration are given below:

31. Bin 'ali bi-yunadīk ... funduq Jadah mustan̄ik. [The son of Ali [the toppled Tunisian presi- dent] calls you.... Jeddah's hotel awaits you.]

32. Wa yadīna fi yadīn ba dịna wa Al-Qadhāfi mā yurhbna. [As long as we join hands, Qathafi will never intimidate us.]

Rhyme is also widely used in Arabic political discourse to embellish it and to attract the attention of addressees. In the slogans under investigation, rhyme has been used over again and again. Some examples are given below:

33. Libya fi al-qalb makānik... Libya namūt 'ala shanik. [Libya! You are in our hearts! For your sake we shall die.]

34. Nị̣na lā khawnah wa lā kilāb... niḥna ma'ākum ya shabāb. [We are neither disloyal [citi- zens] nor dogs, we are supporting you, the Youth.]

35. Ya ima na'ìsh su adā fawqa al-arḍ au shuhadā tahta al-arḍ. [We shall either live happily on earth or martyrs under the earth.]

In addition, different types of morphological repetitions have been noticed in the slogans. Arabic abounds in the use of both pattern repetition and root repetition to fulfil stylistic and rhetorical purposes or as a means of textual cohesion. In (35), the same pattern fu'alā is used in two words su'adā happy' and shuhadā 'martyrs' in close proximity. Root repetition is also common in the slogans. Yemeni revolutionaries who established their camps in a close area to Sana'a University, the top university in the country, chanted: 
36. Là dirāsah wa lā tadrìs hata yasqut al-ra' ̀̄s. [We will neither study nor teach till the presi- dent steps down.]

Here, both dirāsah 'study' and tadrīs 'teaching' are derived from the same root darasa to learn'.

\section{Simile}

Simile is an aesthetic and rhetorical device that is frequently used in the slogans. In a simile, a given entity is compared with another in praise, dispraise, ornamentation, or repugnance using particular words/particles like as or like in English and mithl or ka or $k^{\prime}$ ai in Arabic. The corpus shows that there is a tendency to use single similes in dispraise of the regimes as is shown in (37):

37. Bism kuli al-fanānīn hukmak zift wa zai al-țin. [By the name of all artists your reign is dirty and as filthy as a pigsty/rag.]

In Egyptian Arabic, the word t in is commonly used to refer to something disguisable and bad. Therefore, the reign of Mubarak is compared with țin 'mud'. The colloquial word zai 'like' is used as a simile particle. Thus, both the likened-to and the likened share one feature (i.e. filthiness).

Another example of simile is used by Yemeni protestors, as in (38):

38. Ya ' ali ya safāh ... lā tabki mithla al-timsāh. [O Ali, the shedder of blood ... weep not like a crocodile.]

The slogan refers to Saleh of Yemen, who was bitterly condemned by opponents for giving orders to shoot the innocent demonstrators in Sana'a. More than 50 people were dead and dozens of them were injured. As a result, Saleh has formed an investigation committee to probe into the matter. The protesters consider this step by him as an attempt to hide the heinous crime of killing the peaceful citizens. In their view, the president's weeping and alleged sadness are compared to the tears of the crocodile. Here again, both the likened-to and the likened share one feature (i.e. shedding fake tears).

Hyperbole. The slogan composers have used this mode of semantic embellishment to make excessive exaggeration about the state of someone or something, as in (39) and (40):

39. Ya 'ali irhal irḥal al-kursi tihtak dhahal. [O Ali, Step down! Step down! Your throne has got rusted.]

40. Qul li-Mu'amar wa șigharah al-sha'ab al-Lībi bukrah fi darah. [Say to Muamar and his family, the Libyan people will be in his house tomorrow.] 
In (39), the protesters have chanted that president Saleh must leave power and they claim that his presidential seat got rusted due to the long term he spent in power. In (40), the slogan indicates that the Libyan people as a whole will flood Qadafi's home the following day. The use of this figurative device shows that a considerable number of furious Libyan protestors will reach his palace and will be able to topple him.

Metonymy. Metonymy is frequently used in political discourse in Arabic. It is a figure of speech in which a thing or concept is replaced with the name of something intimately connected to it. Metonymy differs from metaphor. While metaphor's association is by similarity between two concepts, that of metonymy is by contiguity (Courtney, 1990: 75). An example of the use of metonymy is given in (41):

41. Ya 'ali 'ataf farshak... min ta'iz yasqut 'arshak. [O, Ali! Fold your bed... Your throne will certainly fall by the Taizi revolutionaries.]

In the above instance, 'arshak 'your throne' that is associated with royalty and power has been used as metonym for it. A kind of metonymy is synecdoche (i.e. a part of speech in which a specific part of something is used to refer to the whole). This figure of speech has also been frequently used in the slogans, as is obvious in the example above, wherein the phrase 'ataf farshak 'pack and fold your mattress' has been used to refer to the whole process of leaving power. Saleh is not required to pack his bed but to step down. Another example is shown in (42):

42. Ya mubārak ya khasīs dam Al-Mișri mush rakhīṣ. [O Mubarak, the wicked! the blood of the Egyptian is never cheap.]

The expression dam Al-Mișri has been used as synecdoche, in the sense that it is not only the blood of the Egyptians that is not cheap but the Egyptians as a whole are not cheap.

According to Abdul-Roaf (2006: 234) 'the major function of metonymy is to allude to a characteristic feature of someone and cover it up with a given linguistic expression instead of explicitly mentioning it. This pragmatic function is employed by the communicator in both praise and dispraise'. In both (43) and (44), metonymy of attribute is used to refer to the characteristic traits of both Saleh and Qadhafi respectively:

43. Allah yumhil wa lā yuhmil ya 'ali ya 'af āsh. [O, Afash! God's mill grinds slow but sure.]

44. Ya Mu'amar ya bu shafshufah... [Oh Qaddafi abu shafsufah! [a man of shaggy hair].]

Saleh is described as 'af āsh 'a floating useless thing' and Qadhafi is disparagingly called abū shafshufah, or a man with messy and shaggy hair. 
Antithesis. Antithesis is a semantic embellishment, which means the combination of two opposite things whether they are allegorical or non-allegorical. This device is also used in the slogans. Consider, for instance, the following example used by the Libyan protestors:

45. Lā 'ilāh 'ila Allah Al-Qadhāfi 'adu Allah... Lā 'ilāh 'ila Allah al-shahìd ḥabīb Allah. [There is no God but Allah, Qathafi is the enemy of God... There is no God but Allah, the martyr is the beloved of God.]

Here, the antithesis is represented by the occurrence of two contradictory statements: the first is that Qadhafi is the enemy of God and the second is that the martyr is the beloved of Him.

Parallelism. The persuasiveness of the slogans is sometimes heightened through the use of parallel structures, as (46) shows:

46. Thawrah $f \bar{\imath}$ tunis thawra $f \grave{i}$ mașr thawra $f i$ libiya hata al-nașr. [An uprising in Tunisia... An uprising in Egypt and an uprising in Libya until we gain victory.]

Here, three successive clauses within the sentence have employed the same syntactic structure. Another example is illustrated in (47):

47. Ya shabāb ma tikhafush ... Qathāfi ma nibush Ya banāt lā tabkūsh ... al-shuhadā mā yamutūsh. [Oh Youth! Never get scared, we do not want Qathafi anymore. Oh girls, never weep, Martyrs never die.]

Here, the parallel syntactic structure (vocative + noun + negation particle + present verb, noun + negative particle + present verb) is used in the two sentences of the slogan.

Repetition. The rhetorical strategy of repetition is employed in the slogans for a number of reasons including, emphasis, emotional effect, amplification, etc. An example of rhetorical repetition is given in (48):

48. ' 'ahdak wala wala wa rah... lā țawār' ya safāh Thawra thawra silmiyah ... min sahạàt al-ḥuriyah Ya 'ali zūl zūl... h. kukmak ma 'ād lu maf'ūl.

[Your rule has gone has gone ... [There is] no emergency, Blood shedder! An uprising, a peaceful uprising has started in the squares of freedom.

Oh Ali depart, depart, your regime no longer exists.]

\section{Expression structures}

Another element valued in a political discourse is that of expression structures. There is no exaggeration if it is claimed that the protesters left no stone unturned to present their slogans. The way the expression structures of sounds and graphics are shown plays 'an indirect function in emphasizing or de-emphasizing partisan meanings' (van Dijk, 1999: 36). 
While some of the slogans were written to be chanted, they were presented in a skillful graphic manner. Bold fonts and eye-catching colours have been used. The demonstrators have employed and initiated various means through which they express their slogans. The ideational meaning has been expressed through banners, craving in bread, tattoo, graffitists, photographs and drawings. Some slogans have even been written with blood. Thus, different semiotic systems have been used and they worked together semantically (Halliday and Hasan, 1985: 4). This makes slogans a representative genre of social semiotics where meanings are projected via a range of modes, such as language, images, comics, televisions and the like. It has been customary to notice protesters carrying banners with images and texts as has been mentioned earlier. Some slogans have been written, sung and represented visually.

\section{Speech acts and interaction}

A speech act can be defined as the action performed by a speaker with an utterance. A pragmatic analysis of the Arab Spring slogans indicates that the slogans' composers employ several speech illocutionary forces. Many slogans are directives in the form of commands and orders as noticed in (49):

49. Irhal ya'ni imshi ... wila mā tifhamshi. [Depart means leave... Do not you understand?] Encouragement is also a very common speech act in the slogans, as is clear in (50):

5o. Zìd tahadi zīd ya șaqrī al-waḥìd. [Go on in your challenge [to the protesters], Go on, mighty falcon!]

Here, Qadhafi is encouraged by his supporters to be more stubborn and to take the challenge. Some slogans have featured advice and warning as in (51), where the youth are advised to continue their uprising until change is attained. At the same time, the slogan warns them not to launch a long-term uprising because the continuous revolution is destructive chaos:

51. Thawra hata al-nașr wa al-taghyīr wa laysat thawra ìla al-'abad fa-al-thawra almustimarah faudah mudamirah. [The uprising should continue until it wins victory and change is fulfilled. It should not be longer because the continuous uprising means continuous chaos.]

Threat as a speech act is also very prevalent in the slogans, as is stated in (52):

52. 'ah ya hukumat hishik bishik... bukrah al-sha'b Al-Mișri yakushik. [Oh, incompetent/ unworthy government, tomorrow the Egyptian people will throw you out.]

Here, Mubarak's incompetent government is threatened to be swept away. In addition, some slogans serve an assertive function as in (53):

53. Mush hanihda mush ḥaninām ḥata yasqut alniẓām. [We will neither slow down [the pace of our protest] nor will we have a wink of sleep till the fall of the regime.] of our protest] nor will we have a wink of sleep till the fall of the regime.] 
In (53), the protesters assert that they will not calm down till the fall of the regime.

Other speech acts frequently used in the slogans are accusation and counter-accusation. In (54), for example, the pro-Qadhafi demonstrators accuse the Qatar-based Al-Jazeera channel of being notoriously ignoble:

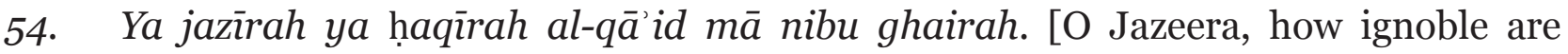
you! We accept none but our leader.]

On the other hand, the anti-regime protesters have apologized to it for the false accusations of Qadhafi supporters, as is clear in (55):

55. Wa Allah manik haqīrah na'tadhir lik ya Al-Jazīrah. [We swear by God you are a channel of vaunted reputation. We apologize to you, Jazeera.]

Denial of accusations raised by opponents is also reflected in a number of other slogans, as is obvious in (34) above and (56):

56. Khazaytana ya 'ali ... ayn Amrīka ayn țali. [You brought us a bad name, Ali... Neither America nor others is behind our uprising.]

In (34), the anti-regime Libyans deny being treacherous and in (57), the anti-regime Yemenis deny the former president's accusation that they are backed by America.

Another political act common in the slogans is that of legitimation. Disclaimer has sometimes been used as a discursive strategy. Several slogans present something positive at first, and then reject it by employing a particular term such as lakin (van Dijk, 1995, 1998). This serves as a positive representation of self-legitimation and negative representation of other-de-legitimation (van Dijk, 1995, 1998, 2006). Consider, for example, the slogan given in (57):

57. Ta iz musalimah wa lakinaha sa-tantafid wa tashta'il radan 'ala mahraqatikum. [Ta 'iz is a city of peace. However, it will revolt in response to your holocaust.]

The slogan shows that the Yemeni province of $\mathrm{Ta}^{\prime} i z$ is peaceful in nature and in practice, but its people will carry the arm to defend themselves as a reaction to attacking the freedom square in Ta'iz. Such an incident has been called al-mahraqah 'the Holocaust' as a reminder of the Holocaust of the Jews at the hands of the Nazi leader, Hitler. The slogan clearly legitimates the use of the arm in the face of the security forces. Similarly, religion has been used as a discourse strategy of legitimizing self-defence and war. The Qurā'nic verse 'kutba 'likum al-qitāl wa hwa kurh lakum' 'Fighting is prescribed for you, and ye dislike it' has been used by protesters in many Arab Spring countries.

As van Dijk (1997: 37) points out legitimization is not 'a speech act in the strict sense, but a complex social act or process that may be accomplished by other speech acts, such 
as assertions, denials, counter-accusations, and so on'. Consider, for example (58), in which Saleh's supporters chant for him to continue in power in compliance with the constitutional and election legitimation. The supporters have counter-argued Saleh's opponents who call for the fall of Saleh's regime. For instance, several speech acts are in play in (58), such as assertion and the denial of the opponents' claim that Saleh is no longer the legitimate president of the Republic:

58. Al-sh'ab yurīd 'ali 'abdallah Șāliḥ wa yujasid baqā'ah ị̣tirām al-shar'iyah aldustūriyah wa al-intikhābiyah alti istmadha min fawzih fi intikhābāt tanafusiyah li-al-riyasah wa al-intikhābiyah alti istmadha min fawzih fi intikhābāt tanafusiyah li-al-riyasah al-yamanyah. [The people want Ali Abdullah Saleh. [His presence embodies respect for the constitutional and election legitimacy he drew from his victory in competitive elections for the presidency of Yemen.]

As opposed to al-shar 'iyah al-dustūriyah 'constitutional legitimation' of the regime, the revolu- tionaries have also legitimated their uprising calling it, al-shar'iyah althawriyah 'revolutionary legitimation'.

Some slogans have also taken the form of questions. The toppled presidents have been questioned on more than one occasion. Mubarak, for example, has been asked by the protesters to clarify how he possessed 70 billion dollars in (59):

59. Ya Mubārak ya țayār minlak 70 milyār. [O Mubarak! The pilot, how can you accumulate a wealth of 70 billion dollar?]

The question here is not a question in the strict sense (i.e. it does not need any answer from the respondent). It rather intends to show how corrupt Mubarak is.

Another illocutionary act in the slogans is that of appeal to God. Both pro- and antiregime in Yemen, for example, appeal and pray to God to help them. While the protesters supplicate to God to assist them to get rid of the president, as is obvious in (60), Saleh's supporters pray to God to grant him victory and success as in (61):

6o. Ya Allah ya allah yasqut 'ali 'abdallah. [We pray to you God! We pray to you God! Ali Abdullah will fall.]

61. Ya Allah ya Allah inșur 'ali 'abdallah. [We pray to you God! We pray to you God! Grant Ali Abdullah your victory.]

It is obvious then that Arab Spring slogans exhibit universal features. Although the current study is not concerned with finding out the specificity of the Arab slogans and their differences from the slogans used worldwide, it would be useful to show some of those differences. In terms of linguistic features, Arab Spring slogans, like slogans used elsewhere, are mapped onto the various levels of linguistics from lexis to pragmatics to enable the demonstrators to coerce, represent and misrepresent, legitimize and delegitimize (Chilton and Schäffner, 1997: 211- 215). In terms of the 
macropropositions or topics of the slogans, the Arab Spring slogans show some difference. Arabs are really preoccupied with the concept of leadership and thus the slogans tend to be more revolutionary. This is somewhat different from slogans produced in other regions, which are for the most part reformist. In addition, the topics of slogans in other regions are likely to be semantically modalized (Lycan, 1994; van Dijk, 1997) in the sense that events and actions may be permitted or obligatory, wished or regretted, and so on (Coates, 1990; Maynard, 1993). Most of the Arab slogans, however, encompass actions that must be fulfilled. In other words, Arab Spring slogans are less semantically modalized for permission, wish or regret. Most of the slogans show the obligatory actions of toppling the regimes, trailing them and humiliating them.

Therefore, it can be claimed that the format of the Arab Spring slogans and slogans in other regions have become rather homogeneous even though their discursive content is increasingly localized. Slogans are widely used in the entire world and their spread can be parallel to McDonaldization (Machin and van Leeuwen, 2004: 99). That is to say, while the formats of McDonald's burgers are the same in the whole world, local versions of McDonald's burgers are sold in different regions in the world.

\section{Conclusion}

The Arab Spring slogans have become an evolving sub-genre of political discourse. The slogans collected from different parts of the Arab world have shown that the slogans meet the various typical discourse structures and strategies that pertain to political discourse at various levels and dimensions. The slogans' topics, textual schemata, local semantics, lexicon, syntax and pro-forms, rhetorical operations and expression structures justify that they are an essential element of the overall political discourse (van Dijk, 1997). The slogans deal with political as well as social topics. They have their own unique schematic structures and superstructures. The local semantics of the slogans tend to better the image of the in-groups and distort the image of out-groups. A lengthy list of words has come into existence during the uprisings. The syntax of the slogan is characterized by brevity, the avoidance of complex sentences, nominalization, special use of pronouns (i.e. positive use of the pronoun 'we' and negative association with the pronoun 'they'), and unique use of foregrounding and backgrounding with a view to emphasizing or deemphasizing something. Besides, the slogans employ a 'smash hits' selection of rhetorical devices. The slogans are full of similes, metaphors, metonymies, antithesis, etc. Prosodic features decorate almost all the slogans. Cohesive devices such as parallelism, ellipsis and morphological repetition are craftily and skilfully used. As for expression structure, slogans appear in different forms and shapes. Some of the slogans are multimodal where text, image and music go hand in hand. Finally, slogans serve multiple speech acts. Directives, questions, appeal and pray, accusation and counter-accusations, legitimation, etc. are found in the slogans. 


\section{Acknowledgements}

The authors thank the anonymous reviewers for their valuable comments and suggestions to improve the quality of the paper.

\section{Funding}

This research received no specific grant from any funding agency in the public, commercial, or not-for-profit sectors. 


\section{References}

Abaza M (2013) Satire, laughter and mourning in Cairo's graffiti. Orient-Institut Studies 2(2013). Available at: http://www.perspectivia.net/content/publikationen/orientinstitut-studies/2-2013/abaza_satire/ (accessed 8 June 2015).

Abdul-Raof H (2006) Arabic Rhetoric: A Pragmatic Analysis. London, UK: Routledge. Al-Haq FA and Hussein A (2012) The slogans of the Tunisian and Egyptian revolutions. In: 42nd Colloquium on African Languages and Linguistics (CALL), Leiden, The Netherlands, 27-29 August 2012. Leiden, The Netherlands: Leiden University Centre for Linguistics.

Billig M (1991) Ideology and Opinions: Studies in Rhetorical Psychology. London, UK: SAGE. Billig M (1995) Banal Nationalism. London, UK: SAGE.

Bitzer L (1981) Political rhetoric. In: Nimmo DD and Sanders KR (eds) Handbook of Political Communication. Beverly Hills, CA: SAGE, pp.225-248.

Bolinger D (1980) Language - the Loaded Weapon: The Use and Abuse of Language Today. London, UK: Longman Group.

Campbell KK and Jamieson KH (1990) Deeds Done in Words: Presidential Rhetoric and the Genres of Governance. Chicago, IL: University of Chicago Press.

Chilton P (1988) Orwellian Language and the Media. London, UK: Pluto Press.

Chilton P (2004) Analyzing Political Discourse: Theory and Practice. London, UK: Routledge.

Chilton PA and Schäffner C (1997) Discourse and politics. In: van Dijk TA (ed.)

Discourse as Social Interaction. London, UK: SAGE, pp.206-230.

Chomsky N and Herman E (1988) Manufacturing Consent: The Political Economy of the Mass Media. New York, NY: Pantheon.

Coates J (1990) Modal meaning: The semantic-pragmatic interface. Journal of Semantics 7(1):53-63. Colla E (2012) The people want. MER 42(263). Available at: www.midanmasr.com/en/article.aspx?ArticleID $=220$ (accessed 8 June 2015).

Condit C and Lucaites J (1993) Crafting Equality: America's Anglo-African Word. Chicago, IL: University of Chicago Press.

Courtney R (1990) Drama and Intelligence: A Cognitive Theory. Montreal, QC: McGillQueen's University Press.

Crystal D (2003) The Cambridge Encyclopedia of the English Language. Cambridge, UK: Cambridge University Press.

Denton R (1980) The rhetorical functions of slogans: Classifications and characteristics. Communication Quarterly 28(2): 10-18.

Dolan FM and Dumm TL (eds) (1993) Rhetorical Republic: Governing Representations in American Politics. Amherst, MA: University of Massachusetts Press.

Dubois S (2013) Streets songs from the Syrian protests. Orient-Institut Studies 2(2013). Available at: http:// www.perspectivia.net/content/publikationen/orient-institutstudies/2-2013/dubois songs (accessed 8 June 2015).

Fairclough NL (1995) Critical Discourse Analysis: The Critical Study of Language. Harlow, UK: Longman. Fawcett P (1997) Translation and Language: Linguistic Theories Explained. Manchester, UK: St Jerome Publishing. 
Gee JP and Handford M (2012) Introduction. In: Gee JP and Handford M (eds) The Routledge Handbook of Discourse Analysis. New York, NY: Routledge, pp.1-6.

Gonzalez-Quijano Y (2013) Rap, an art of the revolution or a revolution in art? OrientInstitut Studies 2 (2013). Available at:

http://www.perspectivia.net/content/publikationen/orient-institut-studies/22013/ gonzalez-quijano_rap (accessed 8 June 2015).

Grabe W and Kaplan RB (1996) Theory and Practice of Writing: An Applied Linguistic Perspective. New York, NY: Longman.

Gribbon L and Hawns S (2012) Signs and signifiers: Visual translations of revolt. In: Mehrez S (ed.) Translating Egypt's Revolution: The Language of Tahrir. Cairo, Egypt and New York, NY: The American University in Cairo Press, pp.103-142.

Halliday MAK (1970) Language structure and language function. In: Lyons J (ed.)

New Horizons in Linguistics. Harmondsworth, UK: Penguin, pp.140-165.

Halliday MAK (1994) An Introduction to Functional Grammar. London, UK: Edward Arnold.

Halliday MAK and Hasan R (1985) Language, Context, and Text: Aspects of Language in a Social-semiotic Perspective. Geelong, Victoria: Deakin University Press

[Republished by Oxford University Press 1989]. Hirschman AO (1991) The Rhetoric of Reaction: Perversity, Futility and Jeopardy. Cambridge, MA: Harvard University Press.

Kaul DK (2010) Continuing Place Discourse - Place Identity and Slogans. Available at: http://panunkashmir.org/blog/ecoculture/continuing-place-discourse-placeidentity-and-slogans (accessed 5 August 2013).

Keraitim S and Mehrez S (2012) Mulid al-Tahrir: Semiotics of a revolution. In: Mehrez S (ed.) Translating Egypt's Revolution: The Language of Tahrir. Cairo, Egypt and New York, NY: The American University in Cairo Press, pp.25-68.

Kiewe A (1994) The Modern Presidency and Crisis Rhetoric. New York, NY: Praeger.

Lahlali M (2014) The discourse of Egyptian slogans: From 'Long Live Sir' to 'Down with the Dictator'. Journal of Arab Media and Society 19: 1-14.

Lu X (1999) An ideological/cultural analysis of political slogans in Communist China.

Discourse and Society 10(4): 487-508.

$\mathrm{Lu}$ X (2004) Rhetoric of the Chinese Cultural Revolution: The Impact on Chinese

Thought, Culture, and Communication. Columbia, SC: University of South Carolina Press.

Lycan WG (1994) Modality and Meaning. Dordrecht, The Netherlands: Kluwer Academic Publishers.

Machin D and Van Leeuwen T (2004) Global media: Generic homogeneity and discursive diversity. Journal of Media and Cultural Studies 18(1): 99-120.

Maynard SK (1993) Discourse Modality: Subjectivity, Emotion, and Voice in the Japanese Language. Amsterdam, The Netherlands: Benjamins.

Neggaz N (2013) Syria's Arab spring: Language enrichment in the Midst of revolution. Language Discourse and Society, 11. Available at: http://www.language-andsociety.org/journal/2-2/1_neggaz_article.pdf (accessed 9 July 2015). 
Sanders L IV (2012) Reclaiming the city: Street art of the revolution. In: Mehrez S (ed.) Translating Egypt's Revolution: The Language of Tahrir. Cairo, Egypt and New York, NY: The American University in Cairo Press, pp.143-182.

Sanders L IV and Visona M (2012) The soul of Tahrir: Poetics of a revolution. In: Mehrez S (ed.) Translating Egypt's Revolution: The Language of Tahrir. Cairo, Egypt and New York, NY: The American University in Cairo Press, pp.213-248.

Sharp H (1984) Advertising Slogans of America. Metuchen, NJ: The Scarecrow Press. Srage N (2013) The Protest discourse: The example of "Irhal" (Go/Get Out/Leave).

Orient-Institut Studies 2 (2013). Available at:

http://www.perspectivia.net/content/publikationen/orient-institut-studies/22013/ srage_protest (accessed 8 June 2015).

Swales J (1990) Genre Analysis: English in Academic and Research Settings. New York, NY: Cambridge University Press.

Taba A and Combs C (2012) Of drama and performance: Transformative discourse of the revolution. In: Mehrez S (ed.) Translating Egypt's Revolution: The Language of Tahrir. Cairo, Egypt and New York, NY: The American University in Cairo Press, pp.69-102.

Tetlock PE (1993) Cognitive structural analysis of political rhetoric: Methodological and theoretical issues. In: Iyengar S and McGuire WJ (eds) Explorations in Political Psychology: Dulce Studies in Political Psychology. Durham, NC: Duke University Press, pp.380-405.

Urdang L and Robbins C (eds) (1984) Slogans. Detroit, MI: Gale Research Company. van Dijk TA (1993) Principles of critical discourse analysis. Discourse and Society 4(2): 249-283.

van Dijk TA (1995) Discourse analysis as ideology analysis. In: Schäffner C and Wenden A (eds) Language and Peace. Aldershot: Dartmouth Publishing, pp.17-33. Available at: http://www.discourse.org (accessed 13 October 2011).

van Dijk TA (1997) What is political discourse analysis? In: Blommaert $J$ and Bulcaen C (eds) Political Linguistics 11(1). Amsterdam, The Netherlands: Benjamins, pp.1152.

van Dijk TA (1998) Ideology: A Multidisciplinary Approach. London: Sage

van Dijk TA (1999) Critical discourse analysis and conversation analysis. Discourse and Society 10(4): 459-450.

van Dijk TA (2006) Politics, Ideology and Discourse. Available at: http://www.discourse.org (accessed 17 March 2011).

Watson J (1999) The syntax of headlines and news summaries in Arabic. In: Suleiman Y (ed.) Arabic Grammar and Linguistics. London, UK: London University Press, pp.161-181.

Wilson J (2003) Political discourse. In: Schiffrin D, Tannen D and Hamilton HE (eds) The Handbook of Discourse Analysis. Blackwell Reference Online. Available at: http://www.blackwellreference.com/subscriber/tocnode?id=g9780631205968_ch unk_g978063120596821> (accessed 9 July 2015).

Windt T and Ingold B (1987) Essays in Presidential Rhetoric. Dubuque, IA: Kendall Hunt. 


\section{Author biographies}

Belqes Al-Sowaidi received her BA in English Language and Literature from Taiz University, Taiz, Yemen in 2000. She was awarded her MA in Translation from the same University in 2006. She obtained her $\mathrm{PhD}$ in Linguistics from the Department of Linguistics, Language and Communication Studies at the University of the Western Cape in 2011. She is currently a research fellow of the University of the Western Cape and an assistant professor at Taiz University,Yemen.

Felix Banda is a professor in the Department of Linguistics at the University of the Western Cape, where he teaches undergraduate and postgraduate courses in critical discourse analysis, the sociolinguistics of multilin- gual society and education, and technology-mediated business communication. His research interests include media and migration studies, linguistic landscapes and the semiotics of corporate identity branding and advertising.

Arwa Mansour received her BA in English Language and Literature from Taiz University, Taiz, Yemen in 1995. She was awarded her MA in Translation from the same University in 2005. She obtained her PhD in Translation from the Department of English, Taiz University in 2010. She is currently the Vice Dean of the Center of Languages and Translation at Taiz University, Yemen.

\section{Appendix}

\section{Internet video files}

Youtube (2011) Allah yumhilwalāyuhmilya aliya afāsh [Online Video]. 8 July. Available at: https:// www.youtube.com/watch?v=LOXkemTVgEA (accessed 20 December 2012).

Youtube (2011) YaḤamādahwayakhalūdqulū li-bābatkummațrūd- Thawrat Al-Yaman [Online Video]. 16 March. Available at:

http://www.youtube.com/watch?v=gaKiPoaKZ3o (Accessed 14 June 2011).

Youtube (2011) Shi 'ārāt min thawrat al-sha 'b Al-Yamanī al-silmiyah [Online Video]. 16

March. Available at: http://www.youtube.com/watch?v=kX2aVqtOpjs (accessed 14 June 2011).

Youtube (2011) Al-thawra Al-Yamanyah: Jom at Al-rahịl-Ta iz [Online Video]. 27 March. Available at: http://www.youtube.com/watch?v=HU1EIm2zmkg (accessed: 14 June 2011).

Youtube (2011) Ajmal hutafāt thawrat khamsah wa ishrīn yanayir amām Masbiro [Online Video]. 11 February. Available at:

http://www.youtube.com/watch?v=tsoE6oPWWwU (accessed 22 June 2011). Youtube (2011) Al-sha'b yurīd isqāt al-hukūmah [Online Video]. 24 January. Available at: http://www.youtube.com/watch?v=X8Xj8gAfjoI (accessed 22 June 2011).

Youtube (2012) January 25, 2011 Qasr el Nil 1:46 PM [Online Video]. 24 January. Available at: http://www.youtube.com/watch?feature=player_embedded\&v=v1ItZFFY_rc (accessed 20 March 2013). 


\section{Other internet sources}

Al-akhbar (2011) Shi'ārāt al-thawrah Al-Yamaniyah: 'ibārāt mujazah lā takhlū min aldu 'ābah [Online]. Available at: www.al-akhbar.com/node/6050 - Saudi Arabia (accessed 19 October 2011).

Aljazeera.net. (2011) Shi ārāt al-thawra bi-dabābāt jaish Mișr [Online]. Available at: http:// www.aljazeera.net/news/reportsandinterviews/2011/2/5/ (accessed 19 April 2011).

Blogspot (2011) ta ríf al-baltajah [Online]. Available at: http://3malamatan.blogspot.com/2008/o6/ blog-post_o8.html (accessed 14 September 2011).

Elaphblog (2011) Shafshufat Al-Qadhāfi [Online]. Available at: http://www.elaphblog.com/ posts.aspx?u=844\&A=78370 (Accessed 20 October 2011).

Maktoob blog (2011) Al-shi ārāt wa al-ḥanājir al-dhahabiya wa 'ahmiyataha fī tabrīr wa tajīj wa injāh al-thawra [Online]. Available at:

http://halaabulail.maktoobblog.com/325/\%D8\%A7\%D9\%84\%D8\%B4\%D8\%B9\% D8\%A7\%D8\%B1\%D8\%A7\%D8\%AA-

D9\%88\%D8\%A7\%D9\%84\%D8\%AD\%D9\%86\%D8\%A7\%D8\%AC\%D8\%B1\%D8\%A7\%D9\%84\%D8\%Bo\%D9\%87\%D8\%A8\%D9\%8A\%D8\%A9 (accessed 19 October 2011).

Muntadyāt ibn Al-Yaman (2011) Shi ārāt al-thawrah Al-Yamanyah [Online]. Available at: http://www.ebnalyaman.com/ip/ipb/index.php?showtopic=20654 (Accessed 20 October 2011).

Muntadayat Jabal Habashi (2011) ma'an li-ajl alf shi 'ār min shi 'ārāt al-thawra alyamanyah [Online]. Available at: http://gaha.ba7r.org/t18174-topic (accessed 14 September 2011).

Shorouknews (2011) Qamūs Al-thawrat Al-'rabiyah: fi al-bad'kanāt (harimna) thumaintahat bi- al-fulūl) [Online]. Available at: www.shorouknews.com/print.aspx?id=474884 - Egypt (accessed 28 October 2011).

Sublat 'umān (2011) 16 ḥaqīqah ghair ma' rūfah 'an Al- Qathāfi wa Libya. [ONLINE] Available at: http://avb.s-oman.net/showthread.php?t=1372017 (accessed 12 August 2015).

Wikipedia, The Free Encyclopaedia (2011) Singing Revolution: Libyan protest slogans. [ONLINE] Available at:

http://en.wikipedia.org/wiki/2011_Libyan_protests_chants (accessed 10 September 2011).

World Bank (2013) Prospects: Middle East and North Africa. [ONLINE] Available at: http://go.worldbank.org/oEJQAoGoCo (accessed 12 August 2015). 